\title{
Enhancing graduate employability through targeting ePortfolios to employer expectations: A systematic scoping review
}

\author{
Lana Mitchell ${ }^{1,2}$, Chris Campbell ${ }^{1,3}$, Mari Somerville ${ }^{1,4}$, Elizabeth Cardell ${ }^{1,5}$ and Lauren T. \\ Williams ${ }^{1,6}$
}

Corresponding author: Lana Mitchell (lana.mitchell@griffith.edu.au)

${ }^{1}$ Griffith University

${ }^{2}$ orcid.org/0000-0002-7892-2131

${ }^{3}$ orcid.org/0000-0001-7749-8538

${ }^{4}$ orcid.org/0000-0002-4699-7278

${ }^{5}$ orcid.org/0000-0002-8327-1003

${ }^{6}$ orcid.org/0000-0002-7860-0319

\begin{abstract}
Electronic portfolios (ePortfolios) are increasingly being used in university degrees to showcase graduate employability. However, evidence on employers' views and use of ePortfolios has not been synthesised. This study aimed to systematically review the evidence on employer, industry representative and university educator views on the use of ePortfolios in recruiting graduates, including recommended ePortfolio content. Six databases were searched to identify original research on views and utilisation of ePortfolios published since 2000 . Studies were screened in duplicate, and the full texts of 163 articles reviewed. Included studies were synthesised to reveal common themes. The 17 included studies represented a range of industries and most were conducted in the USA $(n=10)$. Awareness of ePortfolios was low, as was use within recruitment. Perceived advantages of ePortfolios in recruitment included showcasing key skills/work; ability to comprehensively assess and differentiate between candidates quickly; and accessibility. The main disadvantages were the time taken to review, excessive information and establishing authenticity. Recommended ePortfolios content included samples of professional work, reflections, videos and photos. Inclusion of typical resume content, work experience, skills, transcripts, certificates, references, supervisor evaluations were important, as was a clear and concise structure.
\end{abstract}

Keywords: employability, employers, ePortfolio, graduate, recruitment, resume

\section{Introduction}

Enhancing graduate employability is a key educational role of universities. Employers are seeking graduates with more than the technical knowledge and skills related to the profession; they also want the transferable skills of communication, problem solving, team work, analytical skills (Oliver, 
2013; Stevens, 2008), and reflection (Cleveland, 2018). Thus, many universities have developed employability frameworks to provide students with a sense of mastery, building their professional identity as well as allowing for a range of skill development. The creation and use of a portfolio is one employability strategy.

While hard copy portfolios have a long history of use in education and employment, the rise of electronic versions, or ePortfolios, commenced at the start of the 21st Century. ePortfolios are an online collection of digitised artefacts to demonstrate various skills, resources and accomplishments that represent an individual (Lorenzo \& Ittelson, 2005). There are several distinct advantages of online ePortfolios over hard copy portfolios, such as enhancing students' digital literacy (Lorenzo \& Ittelson, 2005) and creating a product that is easily modifiable (Simatele, 2015), as well as something that can be easily shared in a variety of online modes including email and online platforms. In the digital age, which is heavily invested in technological learning, ePortfolios are receiving increased attention within universities (Pearson et al., 2018).

ePortfolios are a useful tool for collaboration, reflection and facilitating student-centred learning (Kimball, 2005; Pearson et al., 2018), and can encourage an attitude of 'lifelong learning' amongst students (Green, Wyllie, \& Jackson, 2014; Willmarth-Stec \& Beery, 2015). Through an ePortfolio, students are able to critically reflect 'on one's learning and for compiling and demonstrating evidence of learning and skill development' (Krause, 2006, p. 1). ePortfolios also allow for knowledge and skill transfer into other contexts (Penny Light, Chen, \& Ittelson 2012) and the development of metacognitive skills (Pate \& Main, 2017). Of particular interest in educating professionals is the use of ePortfolios in demonstrating competency development (Woodley \& Sims, 2011). Thus universities have a strong interest in the use of ePortfolios as a learning and teaching tool, in career development, and in the transition to employment (Hallam \& Creagh, 2010). However, the way in which employers from a range of industries use ePortfolios in recruitment processes also needs to be considered.

The aim of this scoping review was to review the evidence of employer, industry representative and university educator views and use of ePortfolios related to employability and recruitment. Scoping reviews are becoming increasingly recognised as a valid way of collating the research in an area that has a developing evidence base (Levac, Colquhoun, \& O'Brien 2010; Peterson et al., 2017; Tricco et al., 2016). The purpose of scoping reviews has been highlighted as providing an overview of a research topic, identifying gaps in the area (Peterson et al., 2017). While systematic reviews aim to answer clearly defined questions, scoping reviews focus on broader questions, while still following a systematic process (Tricco et al., 2016).

The specific research questions this scoping review aimed to answer were:

1) To what extent do employers and industry representatives use and plan to use ePortfolios in the recruitment process?

2) In what ways do employers, industry representatives, and university educators' value ePortfolios?

3) How can the use of ePortfolios in graduate recruitment be improved?

\section{Methods}

The methodology outlined by Arksey and O'Malley (2005) and reported by Peterson et al. (2017) was used to guide the scoping review. The authors suggest following five steps: identify the research question; identify relevant studies; study selection; charting the data; collating, summarizing and reporting the results (Arksey \& O'Malley, 2005; Peterson et al., 2017). The PRISMA-ScR (Preferred Reporting Items for Systematic reviews and Meta-Analyses - Scoping Review) (Tricco et al., 2016) was used to guide the reporting of the review. The review protocol was registered with Open Science Framework (available at: https://osf.io/ri53v), as it was not eligible for PROSPERO

Mitchell, L., Campbell, C., Somerville, M., Cardell, E., \& Williams, L. T. (2021). Enhancing graduate employability through targeting ePortfolios to employer expectations: A systematic scoping review. Journal of Teaching and Learning for Graduate Employability, 12(2), $82-98$. 
registration. The first part of the scoping review process was to identify the aim of the study and the research question which has been outlined above.

\section{Identifying relevant studies}

To capture studies relevant to the research question, a systematic literature search was conducted. Key search terms were identified based on the research aims and with assistance from a research librarian. All studies with at least one search term in the article title, abstract, or keywords from the following two categories were included for consideration: 'ePortfolio*' or 'e-Portfolio*' or 'webfolio*' or 'web-folio*' or 'portfolio*' AND 'employment' or 'employability' or 'recruitment' or 'employer' or 'employee'. A search was performed in six databases: Business Source Complete, CINAHL, ERIC, ProQuest, Scopus and Web of Science using the key search terms. Hand searching of reference lists was also undertaken as well as a Google Scholar search to identify additional potential eligible studies with original research. One additional thesis was identified through this means (Dewhurst, 2017). A sample search strategy is outlined in Supplement 1.

\section{Study selection}

The initial search was conducted in October 2018, with an updated search conducted in April 2020 to identify any articles that may have been published since the original search was undertaken. The ePortfolio literature dates back to around the year 2000, although early pioneers such as Barrett were publishing just prior to this time (Barrett, 2000). Articles older than this are not relevant to the current context due to the changing nature of portfolios, including the development of ePortfolios as programs, internet access and improvements to technology, and therefore were not included in this search. Examination of the earlier articles found that they referred to paper-based portfolios rather than using electronic technology (Anderson \& DeMeulle, 1998).

Eligible studies were collated in Endnote X9.3 (Clarivate Analytics, Philadelphia, United States) and exported to Covidence (Veritas Health Innovation, Melbourne, Australia), an online program for managing systematic reviews. Title and abstract screening were conducted in duplicate, using the outlined inclusion and exclusion criteria in Table 1. To ensure screening consistency, 100 articles were initially screened by all reviewers with inclusion and exclusion criteria finalised. Full text screening was undertaken in duplicate, with conflicts resolved through discussion by the two reviewers, with the option of involving a third member of the research team if required.

Table 1: Inclusion and Exclusion Criteria for the Scoping Review of the use of ePortfolios in the Graduate Recruitment Process

\begin{tabular}{|c|c|c|}
\hline Domain & Inclusion Criteria & Exclusion Criteria \\
\hline Time period & 2000 to present (April 2020) & Published prior to 2000 \\
\hline Language & English & Non- English \\
\hline Population & $\begin{array}{l}\text { Employers of university graduates; } \\
\text { industry representatives; university } \\
\text { educators }\end{array}$ & $\begin{array}{l}\text { Graduates seeking employment; any } \\
\text { employment/ career planning for } \\
\text { promotion; university students; school } \\
\text { students; long term workforce; career } \\
\text { change; investors, banking, finance. }\end{array}$ \\
\hline $\begin{array}{l}\text { Intervention } \\
\text { (ePortfolio) }\end{array}$ & $\begin{array}{l}\text { Articles with a key focus on } \\
\text { ePortfolios or online portfolios for } \\
\text { recruitment/employment/ } \\
\text { employability }\end{array}$ & $\begin{array}{l}\text { Generic portfolios (i.e. not specified } \\
\text { ePortfolios or online); paper } \\
\text { portfolios; investment, banking, } \\
\text { business, finance, or retirement } \\
\text { portfolios; portfolio career }\end{array}$ \\
\hline
\end{tabular}

Mitchell, L., Campbell, C., Somerville, M., Cardell, E., \& Williams, L. T. (2021). Enhancing graduate employability through targeting ePortfolios to employer expectations: A systematic scoping review. Journal of Teaching and Learning for Graduate Employability, 12(2), $82-98$. 


\begin{tabular}{lll}
\hline Comparison & No comparison required & \\
\hline Outcome & $\begin{array}{l}\text { Employability; views of ePortfolios } \\
\text { related to employment/ } \\
\text { recruitment; using ePortfolios for } \\
\text { employment/ to enhance } \\
\text { employability }\end{array}$ & $\begin{array}{l}\text { Main focus on employed professionals } \\
\text { evidencing professional development }\end{array}$ \\
\hline Study design & $\begin{array}{l}\text { Original research published in a } \\
\text { peer review journal or thesis with } \\
\text { full text available. }\end{array}$ & $\begin{array}{l}\text { Non- peer reviewed, conference } \\
\text { proceedings or abstract only; } \\
\text { websites, social media }\end{array}$ \\
\hline
\end{tabular}

\section{Charting the data}

Relevant data were extracted into an Excel spreadsheet purpose-developed for this review. Information extracted included authors, year, title, country, profession, study design, aim, type of eP, population, demographics, outcomes and key findings. Data extraction was originally conducted independently (LM), with checking of data against manuscripts conducted by a separate author (MS). Where gaps existed, study authors were contacted via email to provide additional information.

\section{Collating, summarising and reporting the results}

Data were collated based on the key outcomes (employability; views of ePortfolios related to employment/recruitment; using ePortfolios for employment/ to enhance employability) as reported in the studies. The data were then summarised for comparative purposes.

\section{Results}

\section{Database search and screening}

The initial database search in October 2018 identified 4593 publications, with an updated search in April 2020 identifying an additional 423 articles published since the original search (see Figure 1). Overall, 3603 studies were imported into Covidence for screening after most duplicates were removed. Full text screening was undertaken for 163 studies. Seventeen studies were eligible for inclusion in the final review (Table 2). Reasons for excluding publications were an ineligible study design (not original research) ( $n=61$ ), ineligible intervention (not electronic portfolios) $(n=39)$, not an outcome of interest (electronic portfolios) $(n=23)$, not a population of interest (employers/ industry representatives) ( $n=19)$, or full text not available $(n=3)$. 


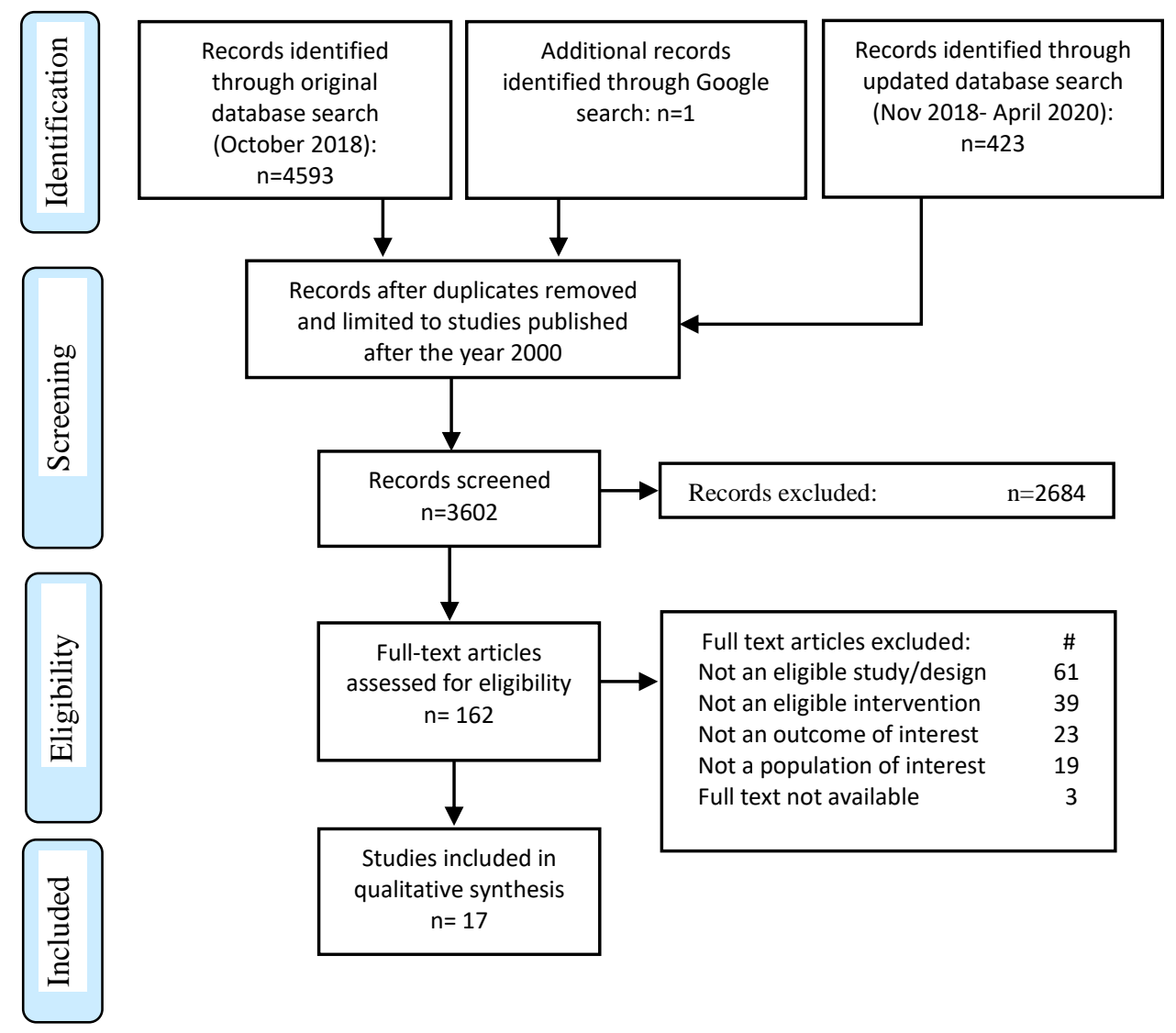

Figure 1: Flow Diagram of the Literature Search and Filtering Results for the Scoping Review of the use of ePortfolios in Graduate Recruitment and Employability.

\section{Characteristics of included studies}

The characteristics of the 17 included studies are outlined in Table 2. The most common setting in which the research occurred was teacher education $(n=6)$, followed by general industry $(n=3)$ and engineering $(n=3)$. The majority of studies were published in the USA $(n=10)$. Survey was the most used data collection method $(n=11)$, followed by individual $(n=4)$ or focus group interviews $(n=3)$, with one using case studies. Participant numbers ranged from six to 107 . The majority of studies did not specify a specific eP platform that was evaluated within the study $(n=14)$. Two studies utilised a platform that was developed by the individual university, and one utilised Google Sites. The outcome measure data extracted related to: awareness and knowledge of ePortfolios; current and expected use of ePortfolios; perceived advantages and disadvantages of ePortfolios; and recommended content for ePortfolios. The detailed key findings of the papers are provided in Supplement 2. 
Table 2: Characteristics of 17 Cross-Sectional Studies included in the Scoping Review for Enhancing Graduate Employability through Targeting eportfolios to Employer Expectations

\begin{tabular}{|c|c|c|c|c|c|c|c|}
\hline $\begin{array}{l}\text { First author, } \\
\text { year, country }\end{array}$ & Profession & Methods & Study Aim & eP platform & Participants & Outcomes assessed & $\begin{array}{c}\text { Support eP } \\
\text { use }\end{array}$ \\
\hline $\begin{array}{l}\text { Chang, 2019, } \\
\text { USA }\end{array}$ & $\begin{array}{l}\text { Engineering and } \\
\text { Science }\end{array}$ & $\begin{array}{l}\text { Survey - } \\
\text { qualitative (5 } \\
\text { open items) }\end{array}$ & $\begin{array}{l}\text { Employer perspectives on } \\
\text { exploring how a reflective } \\
\text { eP enhances student } \\
\text { competitiveness for } \\
\text { future positions. }\end{array}$ & Google Sites & $\begin{array}{l}10 \text { employers: } \\
\text { Academia }(n=4) ; \\
\text { Industry }(n=3) ; \\
\text { National Lab }(n=3) \text {. }\end{array}$ & $\begin{array}{l}\text { Advantages of ePs; } \\
\text { Recommended eP content. }\end{array}$ & Yes \\
\hline $\begin{array}{l}\text { Ciesielkiewicz } \\
\text { 2019, Spain }\end{array}$ & $\begin{array}{l}\text { Teacher } \\
\text { education } \\
\text { (primary and } \\
\text { secondary) }\end{array}$ & $\begin{array}{l}\text { Online } \\
\text { survey - } \\
\text { quantitative } \\
\text { (1 open; } 5 \\
\text { Likert scale) }\end{array}$ & $\begin{array}{l}\text { To explore if school } \\
\text { principals would use an } \\
\text { educational eP for } \\
\text { recruiting purposes. }\end{array}$ & Not specified & $\begin{array}{l}35 \text { School principals (64\% } \\
\text { RR) (Spain } n=23 \text {, Latin } \\
\text { America } n=9 \text {, Africa } n=3 \text { ). }\end{array}$ & Expected use of ePs. & Yes \\
\hline $\begin{array}{l}\text { Clayson, 2019, } \\
\text { USA }\end{array}$ & $\begin{array}{l}\text { Business and } \\
\text { Technical } \\
\text { Communication }\end{array}$ & $\begin{array}{l}\text { Interviews - } \\
\text { qualitative }\end{array}$ & $\begin{array}{l}\text { To explore use of } \\
\text { assessment eP by } \\
\text { employers. }\end{array}$ & Not specified & $\begin{array}{l}7 \text { Business and Technical } \\
\text { Communication employers. }\end{array}$ & $\begin{array}{l}\text { Current \& expected use of } \\
\text { ePs in recruitment; } \\
\text { Advantages of ePs; } \\
\text { Recommended eP content. }\end{array}$ & Mixed \\
\hline $\begin{array}{l}\text { Dewhurst, } \\
\text { 2017, Canada }\end{array}$ & $\begin{array}{l}\text { Medical } \\
\text { Radiation } \\
\text { Therapy }\end{array}$ & $\begin{array}{l}\text { Survey - } \\
\text { mixed ( } 8 \\
\text { closed items; } \\
3 \text { open) }\end{array}$ & $\begin{array}{l}\text { To explore the role of } \\
\text { employment eP in } \\
\text { medical radiation therapy } \\
\text { recruitment. }\end{array}$ & Not specified & $\begin{array}{l}\text { 26: Managers }(n=19) ; \\
\text { Supervisors }(n=4) ; \\
\text { Resource or charge } \\
\text { therapists }(n=2) ; \\
\text { HR employers }(n=1) \text {. }\end{array}$ & $\begin{array}{l}\text { Expected use of ePs in } \\
\text { recruitment; } \\
\text { Advantages \& disadvantages } \\
\text { of ePs; } \\
\text { Recommended eP content. }\end{array}$ & Mixed \\
\hline $\begin{array}{l}\text { Fowler, 2012, } \\
\text { USA }\end{array}$ & $\begin{array}{l}\text { Manufacturing } \\
\text { and nursing } \\
\text { industries }\end{array}$ & $\begin{array}{l}\text { Case studies } \\
\text { - qualitative }\end{array}$ & $\begin{array}{l}\text { To determine if } \\
\text { manufacturing and } \\
\text { nursing employers valued } \\
\text { use of eP in hiring } \\
\text { process, and to develop } \\
\text { suggested template for } \\
\text { eP format for career and }\end{array}$ & Not specified & $\begin{array}{l}12 \text { employers } \\
\text { (manufacturing and } \\
\text { nursing), } 12 \text { cases ( } 6 \\
\text { employers from } \\
\text { manufacturing }+6 \text { from } \\
\text { nursing). }\end{array}$ & $\begin{array}{l}\text { Current \& expected use of } \\
\text { ePs in recruitment; } \\
\text { Advantages of ePs; } \\
\text { Recommendations including } \\
\text { eP content. }\end{array}$ & Yes \\
\hline
\end{tabular}




\begin{tabular}{|c|c|c|c|c|c|c|c|}
\hline $\begin{array}{l}\text { First author, } \\
\text { year, country }\end{array}$ & Profession & Methods & Study Aim & eP platform & Participants & Outcomes assessed & $\begin{array}{c}\text { Support eP } \\
\text { use }\end{array}$ \\
\hline & & & technical education. & & & & \\
\hline $\begin{array}{l}\text { Heinrich, } \\
\text { 2007, New } \\
\text { Zealand }\end{array}$ & $\begin{array}{l}\text { Engineering and } \\
\text { computer } \\
\text { science industry }\end{array}$ & $\begin{array}{l}\text { Interviews - } \\
\text { qualitative } \\
\text { (semi- } \\
\text { structured) }\end{array}$ & $\begin{array}{l}\text { To increase awareness of } \\
\text { characterises of a lifelong } \\
\text { learner and the value of } \\
\text { developing eP. }\end{array}$ & Not specified & 6 Industry representatives. & $\begin{array}{l}\text { Advantages of ePs; } \\
\text { Recommended eP content. }\end{array}$ & Yes \\
\hline $\begin{array}{l}\text { Hsieh, 2015, } \\
\text { Taiwan }\end{array}$ & $\begin{array}{l}\text { Higher } \\
\text { Education }\end{array}$ & $\begin{array}{l}\text { Survey - } \\
\text { quantitative }\end{array}$ & $\begin{array}{l}\text { To review perceptions } \\
\text { related to the } \\
\text { development and } \\
\text { implementation of eP } \\
\text { within Taiwanese } \\
\text { institutions of higher } \\
\text { education. }\end{array}$ & Not specified & $\begin{array}{l}\text { 107: College and university } \\
\text { educators }(n=48) ; \\
\text { Corporate recruiters }(n=59) \text {. }\end{array}$ & $\begin{array}{l}\text { Awareness and knowledge } \\
\text { of ePs; } \\
\text { Current \& expected use of } \\
\text { ePs in recruitment; } \\
\text { Disadvantages of ePs; } \\
\text { Recommendations including } \\
\text { eP content. }\end{array}$ & Yes \\
\hline $\begin{array}{l}\text { Leahy, 2017, } \\
\text { USA }\end{array}$ & $\begin{array}{l}\text { Industry } \\
\text { (general) }\end{array}$ & $\begin{array}{l}\text { Survey - } \\
\text { quantitative } \\
\text { (9 Likert; } 1 \\
\text { open) }\end{array}$ & $\begin{array}{l}\text { To examine employers' } \\
\text { perceptions of } \\
\text { effectiveness of } \\
\text { employment ePs in } \\
\text { evaluating job } \\
\text { candidates. }\end{array}$ & Not specified & $\begin{array}{l}85 \text { recruiters from a range } \\
\text { of industries. }\end{array}$ & $\begin{array}{l}\text { Expected use of ePs in } \\
\text { recruitment. }\end{array}$ & Yes \\
\hline $\begin{array}{l}\text { Leece, } 2005 \text {, } \\
\text { Australia }\end{array}$ & $\begin{array}{l}\text { Industry } \\
\text { (general) }\end{array}$ & $\begin{array}{l}\text { Survey - } \\
\text { quantitative } \\
\text { ( } 7 \text { multi- } \\
\text { choice/ } \\
\text { Likert) }\end{array}$ & $\begin{array}{l}\text { To gather employer } \\
\text { feedback on eP use in } \\
\text { recruitment to university } \\
\text { careers services. }\end{array}$ & Not specified & $\begin{array}{l}55 \text { members of the } \\
\text { Australian Association of } \\
\text { Graduate Employers (23\% } \\
\text { RR). }\end{array}$ & $\begin{array}{l}\text { Awareness and knowledge } \\
\text { of ePs; } \\
\text { Expected use of ePs in } \\
\text { recruitment; } \\
\text { Advantages \& disadvantages } \\
\text { of ePs. }\end{array}$ & Mixed \\
\hline
\end{tabular}




\begin{tabular}{|c|c|c|c|c|c|c|c|}
\hline $\begin{array}{l}\text { First author, } \\
\text { year, country }\end{array}$ & Profession & Methods & Study Aim & eP platform & Participants & Outcomes assessed & $\begin{array}{c}\text { Support eP } \\
\text { use }\end{array}$ \\
\hline $\begin{array}{l}\text { Ndoye, 2012, } \\
\text { USA }\end{array}$ & $\begin{array}{l}\text { Teacher } \\
\text { education } \\
\text { (primary and } \\
\text { secondary) }\end{array}$ & $\begin{array}{l}\text { Online } \\
\text { survey - } \\
\text { mixed } \\
\text { method ( } 21 \\
\text { closed items, } \\
2 \text { open) }\end{array}$ & $\begin{array}{l}\text { To evaluate ePs in the } \\
\text { hiring of } \mathrm{K}-12 \text { teachers. }\end{array}$ & Not specified & $\begin{array}{l}49 \text { school principals ( } 44 \% \\
\text { RR) } \\
\text { (11 counties in south } \\
\text { eastern North Carolina). }\end{array}$ & $\begin{array}{l}\text { Current \& expected use of } \\
\text { ePs in recruitment; } \\
\text { Advantages \& disadvantages } \\
\text { of ePs; } \\
\text { Recommended eP content. }\end{array}$ & Mixed \\
\hline $\begin{array}{l}\text { Painter, 2005, } \\
\text { USA }\end{array}$ & $\begin{array}{l}\text { Teacher } \\
\text { education } \\
\text { (primary) }\end{array}$ & $\begin{array}{l}\text { Focus groups } \\
\text { (example eP) } \\
\text { - qualitative }\end{array}$ & $\begin{array}{l}\text { To understand if and how } \\
\text { ePs are used in the hiring } \\
\text { process, including most } \\
\text { effective content, format, } \\
\text { and use. }\end{array}$ & Not specified & $\begin{array}{l}13 \text { employers in Arizona: } \\
\text { HR staff }(n=6) ; \\
\text { School principals ( } n=5) ; \\
\text { Retired principals/ lecturers } \\
(n=2) .\end{array}$ & $\begin{array}{l}\text { Awareness and knowledge } \\
\text { of ePs; } \\
\text { Current \& expected use of } \\
\text { ePs in recruitment; } \\
\text { Advantages \& disadvantages } \\
\text { of ePs; } \\
\text { Recommendations including } \\
\text { eP content. }\end{array}$ & Mixed \\
\hline $\begin{array}{l}\text { Rowley, 2015, } \\
\text { Australia }\end{array}$ & Music industry & $\begin{array}{l}\text { Survey - } \\
\text { mixed ( } 4 \\
\text { closed items; } \\
9 \text { open) } \\
\text { Focus group } \\
\text { - qualitative }\end{array}$ & $\begin{array}{l}\text { To evaluate how potential } \\
\text { employers of music } \\
\text { graduates perceive ePs in } \\
\text { the workplace. }\end{array}$ & Not specified & $\begin{array}{l}10 \text { music industry } \\
\text { employers. }\end{array}$ & $\begin{array}{l}\text { Current \& expected use of } \\
\text { ePs in recruitment; } \\
\text { Advantages \& disadvantages } \\
\text { of ePs; } \\
\text { Recommended eP content. }\end{array}$ & Yes \\
\hline $\begin{array}{l}\text { Snoeyink, 2007, } \\
\text { USA }\end{array}$ & $\begin{array}{l}\text { Teacher } \\
\text { education } \\
\text { (primary and } \\
\text { secondary) }\end{array}$ & $\begin{array}{l}\text { Focus } \\
\text { groups; } \\
\text { Online } \\
\text { survey - } \\
\text { mixed }\end{array}$ & $\begin{array}{l}\text { To investigate P-12 } \\
\text { school administrators' } \\
\text { perceptions of teacher } \\
\text { education candidates' } \\
\text { online digital portfolios } \\
\text { for hiring purposes. }\end{array}$ & $\begin{array}{l}\text { Individual } \\
\text { university- } \\
\text { developed } \\
\text { tool }\end{array}$ & $\begin{array}{l}23 \text { school personnel } \\
\text { involved in hiring teachers. }\end{array}$ & $\begin{array}{l}\text { Awareness and knowledge } \\
\text { of ePs; } \\
\text { Current \& expected use of } \\
\text { ePs in recruitment; } \\
\text { Advantages of ePs; } \\
\text { Recommendations including } \\
\text { eP content. }\end{array}$ & Yes \\
\hline Strawhecker, & $\begin{array}{l}\text { Teacher } \\
\text { education }\end{array}$ & $\begin{array}{l}\text { Survey - } \\
\text { mixed (17 }\end{array}$ & $\begin{array}{l}\text { To explore the } \\
\text { perspectives of principals }\end{array}$ & Not specified & 37 school principals (from & Expected use of ePs in & Yes \\
\hline
\end{tabular}

Mitchell, L., Campbell, C., Somerville, M., Cardell, E., \& Williams, L. T. (2021). Enhancing graduate employability through targeting ePortfolios to employer expectations: A systematic scoping review. Journal of Teaching and Learning for Graduate Employability, 12(2), 82-98. 


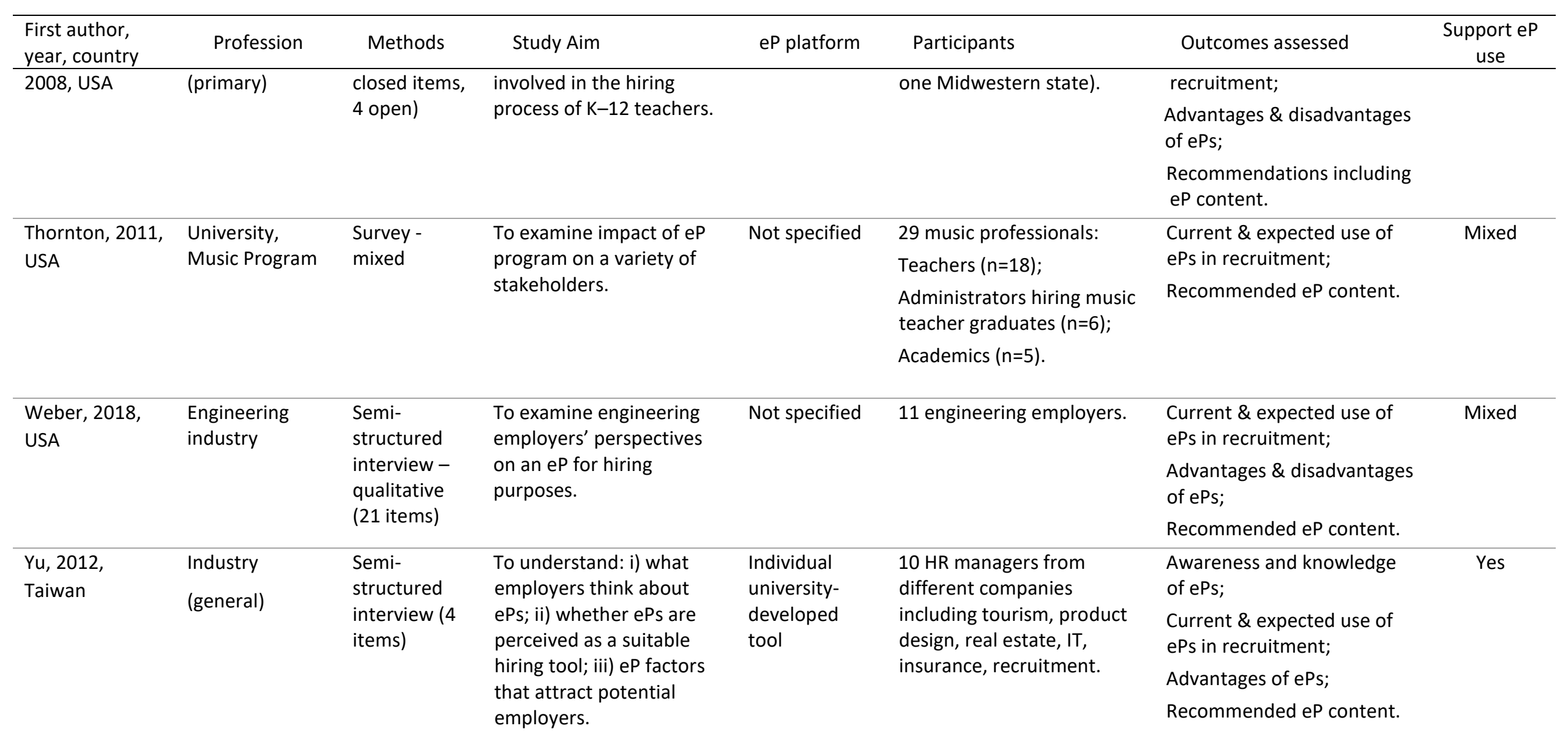

eP=ePortfolio; IT=information technology; RR=Response Rate 


\section{Awareness and knowledge of ePortfolios}

Four studies reported on awareness of ePortfolios, which all showed that at the time of publication (2005-2015) the majority of employers and recruiters had little or no knowledge of ePortfolios (Hsieh, Lee \& Chen, 2015; Leece, 2005; Painter \& Wetzel, 2005; Yu, 2012).

\section{Current and expected use of ePortfolios by recruiters}

Ten studies reported on the current use of ePortfolios. Of these, three reported that participants did not use ePortfolios in the hiring process (Snoeyink \& Meyer, 2007; Weber, 2018; Yu, 2012) and one had limited experience with ePortfolios (Fowler, 2012). The other five studies found mixed levels of use of an ePortfolio. Clayson. (2019), Hsieh et al. (2015), Rowley and Dunbar-Hall (2015) and Thornton et al. (2011), all found that around half of their participants had received an ePortfolio. While Nodye et al. (2012) did not indicate the overall proportion of participants using ePortfolios in recruitment, they indicated that $69 \%$ of participants used them during the interview process, $44 \%$ during initial screening, $24 \%$ after shortlisting, and $14 \%$ after the interview. Despite this experience with ePortfolios, only the study by Clayson (2019) explicitly stated that participants requested ePortfolios during a higher search.

Fifteen of the studies addressed the expected use of ePortfolios, with all showing potential for inclusion in the recruitment process. However, the stage of the recruitment process in which ePortfolios were considered most useful varied $(n=11)$ (see Table 3). Using ePortfolios within the initial job application process of submitting documents was the most common expected use $(n=7)$. Some studies suggested that applicants should be encouraged to provide the URL links on initial application material, including: resumés (Leahy \& Filiatrault, 2017; Painter \& Wetzel, 2005), cover letter (Leahy \& Filiatrault, 2017), application forms (Fowler, 2012) or via email (Leahy \& Filiatrault, 2017). One study suggested that graduates should show potential employers their ePortfolio on a tablet at a career fair (Leahy \& Filiatrault, 2017). While some studies concluded that, in future, ePortfolios will be used in the same way as 'hard copy' job applications (Rowley \& Dunbar-Hall, 2015), or as a supplementary resource (Yu, 2012), others felt that ePortfolios will not replace the traditional resume or application (Fowler, 2012).

Five studies reported that their participants felt ePortfolios would be useful during the initial shortlisting or screening process, with one-third of participants in the Leece (2005) study feeling that this was the most important stage for use. ePortfolios were seen in one study as being easily sent to panel members during job application assessment (Rowley \& Dunbar-Hall, 2015). Other studies reported that the use of the ePortfolios during the initial screening was not as useful (Snoeyink \& Meyer, 2007) or there was not sufficient time to examine them (Painter \& Wetzel, 2005). Four studies reported that their participants saw ePortfolios as being useful during the interview process, however, two studies felt that the interview stage was not appropriate, with the remaining seven studies not commenting on this stage of the recruitment process. Five studies had participants who felt there was a benefit to using an ePortfolio to distinguish between candidates (Painter \& Wetzel, 2005) and make the final hiring decision (Ciesielkiewicz, 2019; Painter \& Wetzel, 2005; Snoeyink \& Meyer, 2007; Weber, 2018; Yu, 2012).

\section{Perceived advantages and disadvantages of ePortfolios}

Twelve studies captured the advantages of ePortfolios from the perspective of employers, industry representatives and university educators. Advantages reported by participants in at least two studies are included in Table 3. The most commonly perceived advantages of ePortfolios for the candidate were the ability of candidate to showcase themselves $(n=6)$; demonstration of key skills $(n=6)$; and provide examples of their work $(n=5)$. Key perceived benefits to recruiters of ePortfolios was the

Mitchell, L., Campbell, C., Somerville, M., Cardell, E., \& Williams, L. T. (2021). Enhancing graduate employability through targeting ePortfolios to employer expectations: A systematic scoping review. Journal of Teaching and Learning for Graduate Employability, 12(2), 82-98. 
capacity for a more comprehensive assessment $(n=6)$; and an enhanced ability to differentiate between candidates $(n=3)$.

Disadvantages highlighted by two or more studies are included in Table 3. The primary disadvantage of ePortfolios from the perspective of employers was the time required for recruiters to review $(n=10)$, due to the large volume of information provided $(n=4)$. Difficulty in establishing authenticity and ability to plagiarise were also identified as barriers $(n=5)$.

Table 3: Preferred Stage of Use and Perceived Advantages and Disadvantages of ePortfolios in Recruitment found in the 16/17 Included Studies Examining these Factors*

\section{Study reference}

\begin{tabular}{|c|c|c|c|c|c|c|c|c|c|c|c|c|c|c|c|c|}
\hline Recommended Stage of use & 1 & 2 & 3 & 4 & 5 & 6 & 7 & 8 & 9 & 10 & 11 & 12 & 13 & 14 & 15 & 16 \\
\hline Initial job application & & $\checkmark$ & & & $\checkmark$ & & & $\checkmark$ & $\checkmark$ & & $\checkmark$ & & & & $\checkmark$ & $\checkmark$ \\
\hline Initial shortlisting/ screening & & $\checkmark$ & & & & & & & $\checkmark$ & $\checkmark$ & & $\checkmark$ & & & $\checkmark$ & \\
\hline Interview & & & & & & & & & $x$ & $\checkmark$ & $\checkmark$ & $\checkmark$ & & $x$ & $\checkmark$ & \\
\hline $\begin{array}{l}\text { Distinguish between } \\
\text { candidates/final decision }\end{array}$ & & $\checkmark$ & & & & & & & & & $\checkmark$ & & $\checkmark$ & & $\checkmark$ & $\checkmark$ \\
\hline $\begin{array}{l}\text { Unclear best time to use in } \\
\text { recruitment process }\end{array}$ & & & & & & & & & & & & & $\checkmark$ & $\checkmark$ & $\checkmark$ & \\
\hline
\end{tabular}

\begin{tabular}{|c|c|c|c|c|c|c|c|c|c|c|c|c|c|c|c|c|}
\hline Advantages & 1 & 2 & 3 & 4 & 5 & 6 & 7 & 8 & 9 & 10 & 11 & 12 & 13 & 14 & 15 & 16 \\
\hline $\begin{array}{l}\text { Ability for candidate to } \\
\text { showcase themselves } \\
\text { (provide additional } \\
\text { information) }\end{array}$ & $\checkmark$ & & $\checkmark$ & $\checkmark$ & & $\checkmark$ & & & $\checkmark$ & $\checkmark$ & & & & & & \\
\hline $\begin{array}{l}\text { Provides more comprehensive } \\
\text { candidate assessment }\end{array}$ & $\checkmark$ & & & $\checkmark$ & & & & & & $\checkmark$ & & $\checkmark$ & $\checkmark$ & $\checkmark$ & & \\
\hline $\begin{array}{l}\text { Provides examples of } \\
\text { candidates' work }\end{array}$ & $\checkmark$ & & $\checkmark$ & & & & & & $\checkmark$ & & $\checkmark$ & & & $\checkmark$ & & \\
\hline $\begin{array}{l}\text { Demonstrates organisational } \\
\text { skills }\end{array}$ & $\checkmark$ & & & & & $\checkmark$ & & & & $\checkmark$ & & & & $\checkmark$ & & \\
\hline $\begin{array}{l}\text { Demonstrates technological/ } \\
\text { creativity skills }\end{array}$ & & & & & & & & & $\checkmark$ & & $\checkmark$ & & & & & \\
\hline $\begin{array}{l}\text { Ease of storing, accessing, } \\
\text { sharing and retrieving } \\
\text { information }\end{array}$ & & & & & & & & & & $\checkmark$ & & $\checkmark$ & & $\checkmark$ & & \\
\hline $\begin{array}{l}\text { Time efficient overview of } \\
\text { candidate/ timely decision } \\
\text { making }\end{array}$ & & & & & $\checkmark$ & & & & & & $\checkmark$ & $\checkmark$ & & & & \\
\hline $\begin{array}{l}\text { Helps to differentiate } \\
\text { between candidates }\end{array}$ & & & & & $\checkmark$ & $\checkmark$ & & & & & & & & & $\checkmark$ & \\
\hline Disadvantages & 1 & 2 & 3 & 4 & 5 & 6 & 7 & 8 & 9 & 10 & 11 & 12 & 13 & 14 & 15 & 16 \\
\hline $\begin{array}{l}\text { Time consuming for recruiters } \\
\text { to review/ lack of time }\end{array}$ & & & & $\checkmark$ & $\checkmark$ & $\checkmark$ & $\checkmark$ & & $\checkmark$ & $\checkmark$ & $\checkmark$ & & $\checkmark$ & $\checkmark$ & $\checkmark$ & \\
\hline $\begin{array}{l}\text { Time consuming for } \\
\text { candidates to develop }\end{array}$ & & & & & $\checkmark$ & $\checkmark$ & & & & $\checkmark$ & & & & & & \\
\hline $\begin{array}{l}\text { Establishing authenticity/ can } \\
\text { be copied/ plagiarism risk }\end{array}$ & & & & $\checkmark$ & $\checkmark$ & $\checkmark$ & $\checkmark$ & & $\checkmark$ & & & & & & & \\
\hline
\end{tabular}

Mitchell, L., Campbell, C., Somerville, M., Cardell, E., \& Williams, L. T. (2021). Enhancing graduate employability through targeting ePortfolios to employer expectations: A systematic scoping review. Journal of Teaching and Learning for Graduate Employability, 12(2), 82-98. 
Large volume of information

to review

Give false sense of applicant/

only best work shown

*Note: only those factors identified by 2 or more sources are included. 1=Chang, 2019; 2=Ciesilkiewicz, 2019; 3=Clayson, 2019; 4=Dewhurst, 2017; 5=Fowler, 2012; 6=Heinrich, 2007; 7=Hsieh, 2015; 8=Leahy, 2017; 9= Leece, 2005; 10=Ndoye, 2012; 11=Painter, 2005; 12=Rowley, 2015; 13=Snoeyink, 2007; 14=Strawhecker, 2008; 15=Weber, 2018; 16=Yu, 2012.

\section{Recommended content for ePortfolio}

Fourteen studies provided insight into the type of content that employers, industry representatives and university educators felt that ePortfolios should contain (outlined in Table 4). Many of these were elements common to traditional paper-based applications, such as the resume/CV $(n=6)$. Many studies recommended including samples of work, in particular professional work $(n=12)$, reflections $(n=11)$, and video $(n=11)$ or photographic $(n=5)$ evidence of work. Including elements in ePortfolios that demonstrate the applicant's skills were commonly suggested, such as technical/professional $(n=4)$, communication $(n=4)$, problem solving $(n=3)$, technology skills $(n=3)$ and teamwork $(n=2)$. In several studies the employers, industry representatives and university educators felt it important that the ePortfolio be clearly structured and easy to navigate $(n=7)$. Five studies highlighted the importance of awareness building and training for enhancing the use of ePortfolios in the recruitment process (data not shown) (Fowler, 2012; Hsieh et al., 2015; Painter \& Wetzel, 2005; Snoeyink \& Meyer, 2007; Strawhecker, Messersmith, \& Balcom, 2008).

Table 4: Recommended Content of ePortfolios, Views of Employers/Recruiters/University Educators in the 14/17 Included Studies Examining these Factors*

\begin{tabular}{|c|c|c|c|c|c|c|c|c|c|c|c|c|c|c|}
\hline \multirow[b]{2}{*}{ Traditional application content } & \multicolumn{14}{|c|}{ Study reference } \\
\hline & 1 & 2 & 3 & 4 & 5 & 6 & 7 & 8 & 9 & 10 & 11 & 12 & 13 & 14 \\
\hline Resume/ CV & $\checkmark$ & & & & & & $\checkmark$ & & $\checkmark$ & $\checkmark$ & $\checkmark$ & & $\checkmark$ & \\
\hline $\begin{array}{l}\text { Introduction to the candidate } \\
\text { (brief bio) }\end{array}$ & & & & & & & & & & $\checkmark$ & & & $\checkmark$ & \\
\hline $\begin{array}{l}\text { Work experience (including } \\
\text { volunteer work, learning } \\
\text { experiences) }\end{array}$ & & $\checkmark$ & & & & $\checkmark$ & $\checkmark$ & & $\checkmark$ & & $\checkmark$ & & & $\checkmark$ \\
\hline Transcripts & $\checkmark$ & & & & & & $\checkmark$ & & $\checkmark$ & & $\checkmark$ & $\checkmark$ & & $\checkmark$ \\
\hline References & & & & & & & $\checkmark$ & & $\checkmark$ & $\checkmark$ & $\checkmark$ & & & \\
\hline $\begin{array}{l}\text { Letters of recommendation/ } \\
\text { endorsements }\end{array}$ & & & & & & & $\checkmark$ & & & & $\checkmark$ & $\checkmark$ & & \\
\hline Certificates/ licences & & & & $\checkmark$ & & & & & & $\checkmark$ & & & & $\checkmark$ \\
\hline Achievements/ Awards & & & & & & $\checkmark$ & & & & & & & & $\checkmark$ \\
\hline $\begin{array}{l}\text { Additional courses (electives) } \\
\text { that were not part of standard } \\
\text { degree structure. }\end{array}$ & $\checkmark$ & & & & $\checkmark$ & & & & & & & & & \\
\hline
\end{tabular}

\begin{tabular}{llllllllllllllll}
\hline Samples of work & 1 & 2 & 3 & 4 & 5 & 6 & 7 & 8 & 9 & 10 & 11 & 12 & 13 & 14 \\
\hline Professional work (university, & & $\checkmark$ & $\checkmark$ & $\checkmark$ & $\checkmark$ & $\checkmark$ & $\checkmark$ & $\checkmark$ & $\checkmark$ & $\checkmark$ & $\checkmark$ & & $\checkmark$ & $\checkmark$
\end{tabular}
paid work, volunteer, other/hobbies)

$\begin{array}{llllllllllllll}1 & 2 & 3 & 4 & 5 & 6 & 7 & 8 & 9 & 10 & 11 & 12 & 13 & 14\end{array}$

Mitchell, L., Campbell, C., Somerville, M., Cardell, E., \& Williams, L. T. (2021). Enhancing graduate employability through targeting ePortfolios to employer expectations: A systematic scoping review. Journal of Teaching and Learning for Graduate Employability, 12(2), 82-98. 
Reflective work (development,

self- awareness, lessons learnt)

Video clip or sound files

(teaching, performances,

conducting tasks)

Photos (professional, extra-

curricular, special events,

represent meaningful idea/

concept)

Supervisor feedback and

comments (student teacher

evaluations)

Evidence of impact

Evidence of experience with

cultural and ethnic diversity

Evidence of community service

activities

Extra-curricular activities

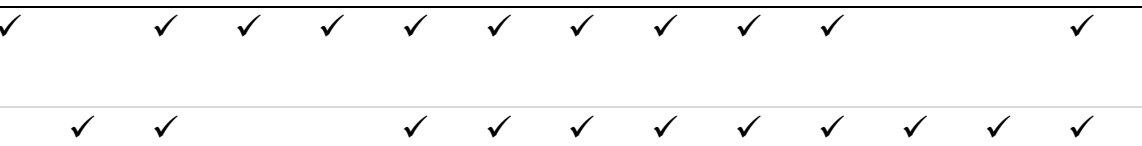

\begin{tabular}{lllllllllllllll}
\hline Demonstration of skills & 1 & 2 & 3 & 4 & 5 & 6 & 7 & 8 & 9 & 10 & 11 & 12 & 13 & 14 \\
\hline Proof of relevant & & $\checkmark$ & & $\checkmark$ & $\checkmark$ & & & & $\checkmark$ & & & &
\end{tabular}

technical/professional skills

Communication skills

(interpersonal, written)

Problem solving

Technology skills \& programs can

use

Evidence of teamwork

\begin{tabular}{|c|c|c|c|c|c|c|c|c|c|c|c|c|c|}
\hline $\begin{array}{l}\text { Personality/ motivations/ } \\
\text { interests }\end{array}$ & 1 & 2 & 3 & 4 & 5 & 6 & 7 & 8 & 9 & 10 & 11 & 12 & 13 \\
\hline Teaching philosophy & & & & & & & $\checkmark$ & $\checkmark$ & & $\checkmark$ & $\checkmark$ & & \\
\hline $\begin{array}{l}\text { Passion and understanding of } \\
\text { organisation/ industry }\end{array}$ & & $\checkmark$ & & $\checkmark$ & $\checkmark$ & & & & & & & & \\
\hline
\end{tabular}

\begin{tabular}{|c|c|c|c|c|c|c|c|c|c|c|c|c|c|}
\hline Structure & 1 & 2 & 3 & 4 & 5 & 6 & 7 & 8 & 9 & 10 & 11 & 12 & 13 \\
\hline $\begin{array}{l}\text { Clear structure \& layout, well } \\
\text { organised }\end{array}$ & $\checkmark$ & $\checkmark$ & $\checkmark$ & & $\checkmark$ & & & $\checkmark$ & & $\checkmark$ & & & $\checkmark$ \\
\hline Free from spelling mistakes & $\checkmark$ & $\checkmark$ & & & $\checkmark$ & & & & & & & & \\
\hline Concise & & & & & $\checkmark$ & & & & & & & & $\checkmark$ \\
\hline $\begin{array}{l}\text { Hyperlink information (ensure } \\
\text { working) }\end{array}$ & $\checkmark$ & & & & & & & & & & & & $\checkmark$ \\
\hline
\end{tabular}

*Note: only those factors identified by 2 or more sources are included. 1=Chang, 2019;; 2=Clayson, 2019;

3=Dewhurst, 2017; 4=Fowler, 2012; 5=Heinrich, 2007; 6=Hsieh, 2015; 7=Ndoye, 2012; 8=Painter, 2005;

9=Rowley, 2015; 10=Snoeyink, 2007; 11=Strawhecker, 2008; 32=Thornton, 13=Weber, 2018; 14=Yu, 2012.

Mitchell, L., Campbell, C., Somerville, M., Cardell, E., \& Williams, L. T. (2021). Enhancing graduate employability through targeting ePortfolios to employer expectations: A systematic scoping review. Journal of Teaching and Learning for Graduate Employability, 12(2), 82-98. 


\section{Discussion}

This scoping review is the first to synthesise employer, industry representative and university educator views and perceived uses of ePortfolios related to graduate employability and recruitment. Despite the search period spanning two decades there were only 17 studies on the topic, the majority of which were published in the last decade. Research into employer, industry representative and university educator views of ePortfolio was most prominent in teacher education, with research in the Health sector limited to one study in nursing (Fowler, 2012) and one in Medical Radiation Therapy (Dewhurst, 2017), both of which were dissertations. With expanded use of ePortfolios in tertiary education (Pearson et al., 2018) the number of studies providing evidence for their use will hopefully also increase. It would also benefit from enhanced methodological rigour, given the included studies were all of cross-sectional design, and based on relatively small participant numbers.

The overwhelming evidence was that ePortfolios were currently under-utilised by the study participants relative to their potential for use. The relatively recent emergence of this literature parallels the development of ePortfolio awareness and use; for instance, two of the four studies reporting low awareness of ePortfolios by employers, were published in 2005 (Leece, 2005; Painter \& Wetzel, 2005). However, the lack of use was only partly due to lack of awareness, with several barriers to use raised by participants in the studies. The primary perceived disadvantage was the time required for candidates to develop ePortfolios and for recruiters to review them. This observation was validated by the Leece (2005) study that reported it was those participants with knowledge of ePortfolios who believed ePortfolios to be too time consuming. The extensive time required for review is due to the large volume of information included within ePortfolios. It is noteworthy that participants in at least one study, that by Heinrich, Bhattacharya and Rayudu (2007), felt the additional information provided in ePortfolios was an advantage that outweighed the additional time cost, however, this observation was in the minority in this scoping review. Other perceived ePortfolio disadvantages were those characteristic of traditional portfolios, including the potential to plagiarise, and providing a false sense of the applicant, with only best work being shown. These perceived limitations are consistent with findings in the literature for traditional employment application processes (Martin, 2016). Factors identified in the studies as increasing the likelihood of considering ePortfolios included prior knowledge of ePortfolios (Leece, 2005; Strawhecker et al., 2008), more years of recruiting experience (Leahy \& Filiatrault, 2017; Strawhecker et al., 2008), and larger size of the employing company (Fowler, 2012).

Despite the current use of ePortfolios in the recruitment process being relatively limited, employers, industry representatives and university educators had several suggestions for the potential use of ePortfolios, particularly in the application phase of the recruitment process. While many of the elements suggested for inclusion were consistent with those included in a traditional application, participants in some studies recognised the unique advantages an ePortfolio format, such as the ability to include video evidence of a sample of work. Photographs were also seen as beneficial elements in some studies, highlighting professional, extra-curricular, and special events, or images that represent idea or something meaningful to the applicant. There was some acknowledgement of the ability of applicants to demonstrate creativity through their ePortfolio itself. Only one study concluded that ePortfolios will be used in the same way as 'hard copy' job applications (Rowley \& Dunbar-Hall, 2015), with another seeing it as a supplementary resource (Yu, 2012). In this more minor utilisation of the platform, a URL link to an online ePortfolio would be submitted with the standard application to use during initial screening and shortlisting (Ciesielkiewicz, 2019; Leece, 2005; Ndoye et al., 2012; Weber, 2018). While Linkedln may be considered a form of online portfolio, it was not used in any of these studies.

Mitchell, L., Campbell, C., Somerville, M., Cardell, E., \& Williams, L. T. (2021). Enhancing graduate employability through targeting ePortfolios to employer expectations: A systematic scoping review. Journal of Teaching and Learning for Graduate Employability, 12(2), 82-98. 
In terms of the second aim of this scoping review, the value placed on ePortfolios by employers, industry representatives and university educators, this varied between studies. Some studies had participants who felt that ePortfolios allowed for a more detailed evaluation of applicant qualities (Ciesielkiewicz, 2019; Weber, 2018; Yu, 2012). Other studies noted the ability for a more detailed assessment of an applicant's potential ability to fit within the employer culture and succeed in the role (Dewhurst, 2017; Thornton et al., 2011). A few studies noted the advantage ePortfolios provided in terms of ease of information storage and access (Ndoye et al., 2012; Rowley \& DunbarHall, 2015; Strawhecker et al., 2008). One study expressed concern that applicants providing ePortfolios may be given preferential treatment in the screening process (Fowler, 2012). Despite some of the studies having positive findings, there was no overwhelming evidence that ePortfolios would replace traditional forms of job applications in the near future.

The final aim of this scoping review was to explore how the use of ePortfolios could be improved. The importance of awareness building and training for enhancing the use of ePortfolios in the recruitment process was highlighted. This could be by educational institutions (Fowler, 2012), conference presentations (Painter \& Wetzel, 2005), standard formats provided for development and rubrics for review (Strawhecker et al., 2008), integration in recruitment systems (Hsieh et al., 2015), training in the technology (Strawhecker et al., 2008) or individuals providing their own ePortfolio link when applying for jobs (Snoeyink \& Meyer, 2007).

The understanding of employer, industry representative and university educator views revealed by this scoping review can be used by ePortfolio software developers to improve software capabilities and enhance marketing material, potentially expanding the perceived value of the software to organisations and users. The training of students in ePortfolio development has the potential to enhance student and new graduate preparedness, confidence and employability. As the field develops, employers and recruiters can potentially benefit from improvements made to ePortfolios based on their feedback in making them more user-friendly.

Utilising scoping review methodology has allowed this review to capture a breadth of concepts related to employer, industry representative and university educator views of ePortfolios in the recruitment process. Searching published literature dating back to the year 2000 has allowed identification of relevant studies since the inception of ePortfolios. A few limitations have been highlighted in this literature. Scoping reviews do not include quality assessments of included studies; therefore, findings have not been evaluated in relation to study quality.

\section{Conclusion}

ePortfolios have the potential to allow employers to make a more comprehensive assessment of the candidate, and to differentiate between candidates. This scoping review showed that the current use of ePortfolios by employers recruiting graduates is limited. While ePortfolios are not likely to replace traditional applications in the near future, the additional benefits that ePortfolios provide allow them to compliment traditional recruitment methods. Understanding employer views of the use of ePortfolios is important given they are the intended target audience of ePortfolios for recruitment. Targeting ePortfolio content to employer preferences could enhance the acceptability of ePortfolios in the recruitment process and thereby enhance graduate employability. Exploration of graduate and students' views of the use of ePortfolios to enhance employability and assist in recruitment, particularly in the areas that include little studies to date such as health professional employment, will be important and needs to be considered in future research.

\section{Acknowledgements}

Funding for this project was provided from the Griffith University Health Group, Dean (Learning and Teaching) (\$3000) as well as Pebble Learning Pty Ltd $(\$ 2500)$.

Mitchell, L., Campbell, C., Somerville, M., Cardell, E., \& Williams, L. T. (2021). Enhancing graduate employability through targeting ePortfolios to employer expectations: A systematic scoping review. Journal of Teaching and Learning for Graduate Employability, 12(2), 82-98. 


\section{Statements on open data, ethics and conflict of interest}

Requests for the data can be addressed to the corresponding author.

This project did not require ethical clearance as data from published studies was systematically reviewed.

The project team has received $\$ 2500$ seed funding from Pebble Learning Pty Ltd, an ePortfolio company, to support a research assistant on this project. These funds have not impacted on results or interpretation of the data.

\section{References}

Anderson, R. S., \& DeMeulle, L. (1998). Portfolio use in twenty-four teacher education programs. Teacher Education Quarterly, 25(1), 23-31.

Arksey, H., \& O'Malley, L. (2005). Scoping studies: Towards a methodological framework. International Journal of Social Research Methodology, 8(1), 19-32. https://doi.org/10.1080/1364557032000119616

Barrett, H. C. (2000). Create your own electronic portfolio. Learning and Leading with Technology, 27(7), 1421.

Ciesielkiewicz, M. (2019). Education for employability: The ePortfolio from school principals' perspective [Article]. On the Horizon, 27(1), 46-56. https://doi.org/10.1108/OTH-01-2019-0001

Clayson, A. (2019). Eportfolios on the job: The use of assessment eportfolios in the business and technical communication job market. Business and Professional Communication Quarterly, 82(4), 458-474. https://doi.org/10.1177/2329490619867457

Cleveland, R. E. (2018). Using digital portfolios: Reflection, assessment \& employment. TechTrends, 62(3), 276285. https://doi.org/http://dx.doi.org/10.1007/s11528-018-0262-0

Dewhurst, J. (2017). Exploring perceptions of professional ePortfolios in the hiring of medical radiation therapists. Ontario: University of Ontario Institute of Technology. https://ir.library.dcuoit.ca/bitstream/10155/870/1/Dewhurst Jennifer.pdf

Fowler, M. (2012). Developing a template for electronic portfolios in career and technical education (Publication Number 88. USA: University of Nebraska-Lincoln. https://digitalcommons.unl.edu/cehsedaddiss/88

Green, J., Wyllie, A., \& Jackson, D. (2014). Electronic portfolios in nursing education: A review of the literature. Nurse Education in Practice, 14(1), 4-8. https://doi.org/10.1016/i.nepr.2013.08.011

Hallam, G., \& Creagh, T. (2010). ePortfolio use by university students in Australia: A review of the Australian ePortfolio Project. Higher Education Research \& Development, 29(2), 179-193. https://doi.org/https://doi.org/10.1080/07294360903510582

Heinrich, E., Bhattacharya, M., \& Rayudu, R. (2007). Preparation for lifelong learning using ePortfolios. European Journal of Engineering Education, 32(6), 653-663 https://doi.org/10.1080/03043790701520602

Hsieh, P.-H., Lee, C.-I., \& Chen, W.-F. (2015). Students' perspectives on e-portfolio development and Implementation: A case study in Taiwanese higher education. Australasian Journal of Educational Technology, 31(6), 641-656. https://doi.org/10.14742/ajet.1605

Kimball, M. (2005). Database e-portfolio systems: A critical appraisal. Computers and Composition, 22(4), 434458. https://doi.org/https://doi.org/10.1016/i.compcom.2005.08.003

Krause, K. L. (2006). ePortfolios for graduate students: A discussion paper. Melbourne: Centre for the Study of Higher Education, University of Melbourne. http://citeseerx.ist.psu.edu/viewdoc/download?doi=10.1.1.460.555\&rep=rep1\&type=pdf

Leahy, R. L., \& Filiatrault, A. (2017). Employers' perceptions of the benefits of employment electronic portfolios. International Journal of ePortfolio, 7(2), 217-223.

Leece, R. (2005). The role of e-portfolios in graduate recruitment. Australian Journal of Career Development, 14(2), 72-79. https://doi.org/http://dx.doi.org/10.2255/1038-4162.14.2.0028

Levac, D., Colquhoun, H., \& O'Brien, K. K. (2010). Scoping studies: Advancing the methodology. Implementation Science, 5(69), 1-9. https://doi.org/10.1186/1748-5908-5-69

Lorenzo, G., \& Ittelson, J. C. (2005). An overview of e-portfolios. USA: EDUCAUSE Learning Initiative. http://electronicportfolio.pbworks.com/f/reading04overview.pdf

Mitchell, L., Campbell, C., Somerville, M., Cardell, E., \& Williams, L. T. (2021). Enhancing graduate employability through targeting ePortfolios to employer expectations: A systematic scoping review. Journal of Teaching and Learning for Graduate Employability, 12(2), 82-98. 
Martin, B. (2016). Plagiarism, misrepresentation, and exploitation by established professionals: Power and tactics. In T. Bretag (Ed.), Handbook of Academic Integrity (pp. 913-927). NSW: Springer. https://link.springer.com/content/pdf/10.1007\%252F978-981-287-098-8.pdf\#page=913

Ndoye, A., Ritzhaupt, A. D., \& Parker, M. A. (2012). Use of ePortfolios in K-12 teacher hiring in North Carolina: Perspectives of school principals. International Journal of Education Policy and Leadership, 7(4), 1-10. https://doi.org/https://doi.org/10.22230/ijepl.2012v7n4a336

Oliver, B. (2013). Graduate attributes as a focus for institution-wide curriculum renewal: Innovations and challenges. Higher Education Research and Development, 32(3), 450-463. https://doi.org/10.1080/07294360.2012.682052

Painter, S., \& Wetzel, K. (2005). School administrators' perceptions of the use of electronic portfolios in K-8 teacher hiring. Journal of Computing in Teacher Education, 22(1), 23-29. https://doi.org/ https://doi.org/10.1080/10402454.2005.10784532

Pate, H., \& Main, S. (2017). Constructing the pathway: Supporting student employability in an Education program. ePortfolio Forum: Owning, supporting and sharing the journey. Brisbane: eLearning Services.

Pearson, A. G., Harris-Reeves, B. E., Mitchell, L. J., \& Vanderlelie, J. J. (2018). Use of ePortfolios in health professions education. In I. Singh \& K. Raghuvanshi (Eds.), Emerging technologies and work-integrated learning experiences in allied health education (pp. 208-233). IGI Global. https://doi.org/10.4018/978-15225-3850-9.ch011

Penny Light, T., Chen, H. L., \& Ittelson, J. C. (2012). Documenting learning with ePortfolios: A guide for college instructors. USA: Wiley.

Peterson, J., Pearce, P. F., Ferguson, L. A., \& Langford, C. A. (2017). Understanding scoping reviews: Definition, purpose, and process. Journal of the American Association of Nurse Practitioners, 29(1), 12-16. https://doi.org/https://doi.org/10.1002/2327-6924.12380

Rowley, J., \& Dunbar-Hall, P. (2015). The role of ePortfolios in preparing students for music careers. Australian Journal of Music Education, 2, 216-223.

Simatele, M. (2015). Enhancing the portability of employability skills using e-portfolios. Journal of Further and Higher Education, 39(6), 862-874. https://doi.org/10.1080/0309877X.2014.953461

Snoeyink, R., \& Meyer, J. (2007). Shaping teacher candidates' digital portfolios: What administrators want for hiring. Journal of Computing in Teacher Education, 23(3), 89-96. https://doi.org/ https://doi.org/10.1080/10402454.2007.10784567

Stevens, H. (2008). The impact of e-portfolio development on the employability of adults aged 45 and over. Campus-Wide Information Systems, 25(4), 209-218. https://doi.org/10.1108/10650740810900658

Strawhecker, J., Messersmith, K., \& Balcom, A. (2008). The role of electronic portfolios in the hiring of K-12 teachers. Journal of Computing in Teacher Education, 24(2), 65-71. https://doi.org/https://doi.org/10.1080/10402454.2007.10784588

Thornton, L., Ferris, N., Johnson, G., Kidwai, K., \& Ching, Y. H. (2011). The impact of an e-portfolio program in a music education curriculum. Journal of Music Teacher Education, 21(1), 65-77. https://doi.org/10.1177/1057083710397592

Tricco, A. C., Lillie, E., Zarin, W., O’Brien, K., Colquhoun, H., Kastner, M., Levac, D., Ng, C., Sharpe, J. P., \& Wilson, K. (2016). A scoping review on the conduct and reporting of scoping reviews. BMC Medical Research Methodology, 16(1), 15. https://doi.org/https://doi.org/10.1186/s12874-016-0116-4

Weber, K. (2018). Employer perceptions of an engineering student's electronic portfolio. International Journal of ePortfolio, 8(1), 57-71.

http://search.proquest.com.libraryproxy.griffith.edu.au/docview/2101386278?accountid=14543

Willmarth-Stec, M., \& Beery, T. (2015). Operationalizing the student electronic portfolio for doctoral nursing education. Nurse Educator, 40(5), 263-265. https://doi.org/http://dx.doi.org/10.1097/NNE.0000000000000161

Woodley, C., \& Sims, R. (2011). EPortfolios, professional development and employability: Some student perceptions. Campus-Wide Information Systems, 28(3), 164-174.

https://doi.org/10.1108/10650741111145698

Yu, T. (2012). E-portfolio, a valuable job search tool for college students. Campus-Wide Information Systems, 29(1), 70-76. https://doi.org/http://dx.doi.org/10.1108/10650741211192064

Mitchell, L., Campbell, C., Somerville, M., Cardell, E., \& Williams, L. T. (2021). Enhancing graduate employability through targeting ePortfolios to employer expectations: A systematic scoping review. Journal of Teaching and Learning for Graduate Employability, 12(2), 82-98. 